\title{
Living through, living with and living on from breast cancer in the UK: creative cathartic methodologies, cancerous spaces and a politics of compassion
}

\section{Clare Madge}

Department of Geography, University of Leicester, LE1 7RH cm12@le.ac.uk, 0116-252-3643

This paper contributes to a growing literature exploring the embodied emotions involved in death studies. It does so through a creative cathartic autobiographical account of living through and on from breast cancer. In presenting this 'storifying experience', this UK-based paper has three key aims: first, it attempts to counter the disjuncture between the fleshy and emotional cancer journey I have travelled through and the sometimes abstract, disembodied accounts of cancer circulating in some geographical texts; secondly, it reveals some geographical insights that are uncovered through the use of creative cathartic methodologies which unsettle commonly held discourses about dying and surviving; and, thirdly, it poses some troubling questions for geographers working in this field with respect to the methodologies, politics and emotions of such research. In the paper I argue that employing creative cathartic methodologies gesturs towards 'an opening into learning' that provokes emotional enquiries about what it means to be taught by the experience of (traumatised) others. In particular, I advocate for a politicised compassion that both cares for those who are living through, with or living on from life-threatening illnesses but also cares about the complex conditions that shape their experiences, both within and beyond the academy.

Key words: Geographies of dying, creative cathartic methodologies, autobiography, breast cancer emotions, compassion. 


\section{Breast cancer, autobiography and creativity}

\section{Geographies of death and dying: living through, living with and living on}

Studies of death, dying, bereavement and mourning are rapidly becoming a vibrant arena of geographical enquiry. Work has revolved around uncovering the various deathscapes of dying and bereavement (Evans 2014; Glover and Parry 2009; Maddrell and Sidaway 2010; Morris and Thomas 2005), exploring landscapes, sites and cultures of remembrance and mourning (Gin 2013; Jenkings et al. 2012; Maddrell 2013) and revealing death work, dead body politics and corpse geographies (Tyner 2014; Young and Light 2013). Literature has explored the varied experiences of different populations groups, as viewed from the perspective of medical practitioners, families and 'patients' (Froggatt et al. 2011; Liaschenko et al. 2011; Moore et al. 2013). A variety of methodologies have been employed in these studies, ranging from more quantitative, spatial analysis of death rate statistics to more qualitative, participatory accounts of research with dying/grieving people. What strikes me, however, is how curiously devoid of passion, how disembodied, dare I say, almost emotionally sanitised some of these accounts actually feel. Where are the hurting, aching, grieving bodies? Where are the accounts of the determined, resolute will to survive? Where are the tender, desperately sad or angry narratives? Where are the stories of the demanding and troubling burdens such research places on the researcher? Surely the topic of death, dying, bereavement and mourning is more challenging, more visceral and certainly downright more painful than some of these texts might suggest ${ }^{\text {i? }}$ To this end, the impulse to write this paper is to contribute to a growing literature exploring the embodied emotions involved in death and grieving (Maddrell 2009; O’Neill 2009; Sidaway 2009; Tucker 2010). Maddrell (2013), for instance, explores the ways in which emotions, memories and materiality of absence through death are expressed and negotiated in different memorial forms and landscape settings, while Gould (2010: 283) scrutinises 'the task that death leaves us with; the work of mourning' through looking at, thinking about and making artworks. 
This paper attempts to add to this scholarship on the emotive angle of geographies of death and dying, by presenting an unsettling autobiographical narrative of living through and on from the serious life-threatening illness (breast cancer) ${ }^{\mathrm{ii}}$. In producing an emotional ‘minded-body’ (HayesConroy 2010) account that is written from and through the body, I attempt to move beyond simple oppositions of dying/living, cancer victim/cancer survivor, mind/body, emotions/corporeality to explore some key questions surrounding the geographies, methodologies, and politics of undertaking research in this field, as seen through the 'eyes' of someone (in a specific social and spatial context) whose own sense of mortality has been brutally sharpened. Such an 'illness narrative' can offer insight into living through, on and with a life-threatening illness as it is actually experienced (following the tradition of Frank 2000, Kleinman 1988 and Sontag 1983). In presenting this 'storifying experience', the paper therefore has three key aims: first, it attempts to counter the disjuncture between the fleshy and emotional cancer 'journey' I have travelled though and the sometimes abstract, disembodied accounts of cancer circulating in some geographical texts; secondly, it reveals some geographical insights that are uncovered through the autobiographical frame which unsettle commonly held discourses about dying and surviving; and, thirdly, it poses some troubling questions for geographers working in this field with respect to the methodologies, politics and emotions of such research. As such, it responds to Bondi's (2005: 231; 2014a: 53) call for a wider appreciation and understanding of the emotions involved in research practice and Tamas' (2009: 1) questioning of how 'to write ourselves differently' in trauma studies.

The focus on 'living through, living with and living on' is of increasing importance given improvements in screening and treatments (in some places) mean many more people (in some places) are 'surviving' life-threatening illnesses or living longer with them (Watts 2010), with the emotional, physical and financial consequences of the illness remaining long after diagnosis. For example in the UK (the location from which I write), although breast cancer is the most common form of cancer in the UK with a lifetime risk effecting one in eight women, between 2005 and 2009 85 per cent of adult female breast cancer patients in England survived their cancer for five years or 
more (http://www.cancerresearchuk.org/cancer-info/cancerstats/types/breast/), with 480,000 people in the UK living with and on from breast cancer (NCSI 2013: 20) ${ }^{\mathrm{iii}}$. As Harrington et al. (2010) illustrate, however, many of those 'living on' will experience physical symptoms or side effects for more than 10 years after treatment, resulting in long-term impact. These include traumatic emotional stress, loss of confidence over everyday body functions, the effect of physical disfigurement on sexual identity and inter-personal relations, increased isolation and a reduced ability to return to work following treatment, with resultant loss in income as a direct result of cancer (Macmillan Cancer Support 2014; Tighe et al. 2011). Indeed, the National Cancer Survivorship Initiative (NCSI 2013: 23) documents a one-third reduction in employment one year from a cancer diagnosis: living through, with and on from a cancer diagnosis is an enduring affair which requires greater research attention ${ }^{\text {iv }}$. In this paper I intend to do so through the autobiographical lens.

\section{Autobiographical creative cathartic methodologies}

Autobiography is a methodological approach that has been employed sparingly in the geographical literature on death and dying, although Gould (2010), O’Neill (2009) and Tucker (2010) do give poignant accounts of memory, mourning and loss. It has been used more often in the critical health/disability literature, often to counter biomedical detachment and to explore the complexities of researching illness and disability 'from the inside' (Worth 2008) ${ }^{\mathrm{v}}$. Milligan et al. (2011), for example, have utilised elicited autobiographies to chart the career journeys of mental health activists to provide insights into the 'triggers and trajectories' underpinning mental health activism and Chouinard (2012) has made a thematic narrative analysis of autobiographies of people living with bipolar disorder to explore their altered ways of 'being in place'. In a similar vein, Dickinson and Sothern (2013) have used autobiographical texts to uncover the multiple relations of care involved in organ transfers while Davidson and Henderson (2010a) have analysed autobiographies 
and personal narratives of people on the autism spectrum to reveal their discursive repertoires of concealment and disclosure about their condition.

While these studies focus on the analysis of narrative prose produced by others, here I join Bissell (2010) and Moss (1999; 2014) who give personal reflections on pain and chronic illness, and Vanolo (2014) and Bondi (2014b) who give personal accounts of psychoanalytic therapy and more ordinary feelings of insecurity, to contribute to the growing genre of 'intimate writing' (Donovan and Moss 2014). I will use a self-created varied autobiographical format- a creative bricolage- including photographic images, creative writing and 'poetry' ${ }^{\text {vi }}$. These are just three sources (see Figures 1, 2 and 3) of a book of 'cathartic exhalations' that I created whilst undergoing treatment for breast cancer, starting May 2009, based in Leicester, UK. I used these creations in the process of attempting to fathom the intricacies of facing a life-threatening illness, as I was passing through it, with an unknown end-outcome. They facilitated a vital process of catharsis that enabled me to express the unspeakable and engage in reverie (Tamas 2014a: 91), helping me to process and contemplate my cancer diagnosis and treatment. These sources are deliberately and unashamedly autobiographical- a being-knowing approach (Hulme 2013)- and they paint a picture of living through and on from 'the inside', from one minded-body going through this particular experience. This self-presentation is not from some egocentric narcissism or from a position of sublime individual contemplation but because, as Frida Kahlo used to respond when she was asked why she painted herself so often, 'I am the subject I know best' (Kettenmann 2002: 27). As such, I am using my three experiential creations as an instrument of understanding, using my minded-body as a research tool, to produce a form of 'embodied storytelling' (Daya 2011; Longhurst 2012), which sheds a fresh (geographical) perspective on the everyday realities of living through and on from cancer. I therefore embrace autobiography as a means to attempt to make sense of the perplexing, fleshy, difficulties of the human experience of livingdying from cancer, and the emotional, embodied and political context of that experience, albeit from a particular framing or perspective ${ }^{\mathrm{vii}}$. 
These three creative sources are clearly partial and situated (i.e. written from the frame of someone experiencing one specific illness, with a particular knowledge of that illness, located in the precise place of Leicester UK, with its particular system of health care provision, embedded in specific social and political networks and experienced through a distinct minded-body). Cancer is, however, a prevalent worldwide disease that is a part of many people's (often unspoken) everyday lives. As a health issue of (differential) global significance, it is therefore a topic of important consideration. Moreover, I do intend to 'extrapolate out' from these 'self-sources', using them as a pivot to consider broader questions about the methodologies, politics and emotions of living through, with and on from cancer. This is partly because such experiences of (im)mortality locate us in a web of relations with others (family, friends, medicinal/therapeutic practitioners, designers of medical equipment etc) in which there is 'a mutual enfolding of self and world that inevitably moves us beyond the singular personal experience' (Hawkins 2011: 467). The creative autobiographical bricolage is thus presented both as explicit testimony but also as a fulcrum for broader critical reflection. Hence I follow Longhurst (2012: 876) and Purcell (2009: 34) in using several different approaches to autobiography: phenomenological (to capture the felt experience of everyday life), reflexive (to critically examine my own subjectivity) and insurgent (to destabilise dominant assumptions about cancer). In this manner, I grapple with 'a multiple positionality that facilitates the translation of experience and knowledge' (Butz 2010: 151) and involves a 'balancing act between engagement with ourselves as minded-bodies, capable of making contributions to our research but also of loosing ourselves in our own reflections' (Shaw 2013: 3). Additionally, such autobiographical creations do not simply 'exist': they are enacted through particular relations of social and political power and wider discourses and knowledge systems to produce multiple meanings and identifications of what it 'means' to live with cancer (de Shazer 2012; Krupar 2012). In other words, this embodied story is also inevitably connected to dominant intellectual regimes about cancer and these discursive spaces have also partially shaped my minded-body creative autobiographical account of livingdying. 
The three autobiographical pieces I present below are cathartic but they are creative too, and as such, this paper also adds to the burgeoning literature on the creative (re)turn in geography (Hawkins 2012; Madge 2014). For example, the potentials of art (Báez-Hernández 2012), poetry (Shafi 2010), video (Parr 2006) and photography (Jay 2012) for researching health matters and improving medical education (de Leeuw et al. 2014) are now are coming under greater scrutiny, although there are still only a limited number of works dealing with the creative moment, death, mourning and trauma (Gould 2010; O’Neill 2009; Tamas 2014a; Tucker 2010). Rather than looking at creativity as something outside of myself, however, I write this paper as a creative agent, as the subject and producer of creativity. This is an approach which transcends author/object, insider/outsider, body/mind of representation dichotomies (Butz and Besio 2009). Through my autobiographical creations, I make the case for tender, fleshy, geographic expression which can 'breathe life' into the humanity of the 'lived reality' of going through a cancer diagnosis, allowing for 'visceral resonance' (Sherry and Schouten 2002: 218). Creative expression can therefore help 'write' geographies of livingdying in a passionate manner using a methodology that 'speaks through the body' (Duffy 2013). In bringing in 'findings from the margins' (Katz 2013), creative expression can have transformative potential too because it can enact the world in novel and surprising ways. So the three autobiographical pieces I present below are not simply a symbol of self-determination and survival, but they also show that creative methodologies can 'bring alive' geographies of livingdying alongside more traditional formats of writing. For example, this paper employs traditional academic writing, empirical secondary health care data as well as autobiographical reflection. Accordingly, it traverses between speaking positions- personal (I), detached (one), communal (we)- in a deliberately mobile authorial move; the 'master narrative' is further unsettled through a dialogic stance which seeks to ask questions of myself and the reader. As such, this paper is not a demand that emotionally-laden accounts are the 'best' way to represent livingdying; rather, it is a suggestion that richly evocative and intimate writing (Donovan and Moss 
2014) might add to the range of methodologies employed by geographers interested in death and dying.

\section{Reading and viewing positions}

At this point I must also add something about reading this paper, for it may not necessarily be an easy paper to read. Some people reading this paper may have experience of cancer (either personally or having a family or friend who is living with cancer, living through it, or has sadly died from it), or other life-threatening illnesses and losses. This paper does not shy away from my fleshy experience of the stark realities of a cancer diagnosis. As such, an active and affecting encounter may be created with the reader of this paper, so it may be an emotionally demanding read for some, triggering memories of loss and feelings of grief ${ }^{\text {viii }}$. I am therefore troubled by publishing this paper, and the complex responsibilities which connect me to the reader. Indeed, I still have reservations including questions such as: Are my cathartic creations 'good enough'? Am I exposing myself too much through their emotive form? How can I release into a public arena such personal ideas, feelings and imaginings while still caring for my soul? And why would I want to do so? Does the paper move beyond personal catharsis to hold analytical resonance, value and worth and in asking this question, what 'god-trick' am I falling into? How and why might the paper trigger a (varied) emotional response in the reader and in what ways might this matter? These are important questions I return to in the conclusions, for as Hawkins (2011: 472) notes, 'it can be hard to study, and even harder to write about, these personal and experiential ways of knowing.'

Additionally, the paper raises questions about the 'embodied acts' of research into livingdying. Here I am encouraging the reader towards care-full viewing, which might involve looking and looking again, to move beyond surface appearances, thereby challenging the idea that by merely looking we can see (hooks 1995: 36). All photographic images used in the three creative sources are mine, and here I am acutely aware of the sensitivity of such images for some viewers for whom images of hairless, cannulated bodies in Figures 1 and 2 may evoke tender feelings and 
memories. But my intention is not simply to 'open up' this paper to the acknowledgement that people have gone (and at this precise moment in time are going) through the painful process of dying, living with and surviving cancer; rather, my purpose is to refute the dehumanisation of disembodied accounts. By evoking such images alongside the fecundity and fertility of Figure 3, the intention is to stand beside the pain of such images with a sense of vitality. Although this makes for challenging viewing, the purpose is to confront regimes of visuality that may enforce abstract studies of livingdying, sometimes especially through absence. So in portraying that which often remains concealed and invisible (painful, ill and dying bodies), I am deliberately inserting the humanising but problematic status of the surviving minded-body into this academic account to counter the emotional and visceral desert of (some) livingdying accounts.

The argument (and paper) unfolds in four sections ${ }^{\mathrm{ix}}$. In this first section the study has been placed in the context of the literature, including a discussion of the autobiographical approach used (a 'creative cathartic methodology'). The three cathartic sources are then integrated into the text. The remainder of the paper uses these sources as a fulcrum to critically consider the potentials of creative cathartic methodologies in terms of what we research (section two), how we research (section three) and why (section four). So section two explores what geographical insights might be gleaned from using such creative cathartic methodologies while section three is an emotional reflection on the research methodology. The final section four gestures towards 'an opening into learning' that provokes, unsettles and raises enquiries about what it means to be taught by the experience of (traumatised) others, advocating the need for a politicised compassion that both cares for those who are living through, living with or living on from life threatening illnesses, but also cares about the complex conditions that shape their experiences, both within and beyond the academy.

Insert Figure 1 here

Insert Figure 2 here 
Insert Figure $3^{x}$ here

\section{Geographical insights}

In this section I explore three particular geographic contributions that might be gleaned from the creative cathartic sources. First, I argue that such sources can help to reveal the complexities of cancerous spaces. They do so by illustrating that different minded-bodies have varied responses to cancer diagnosis and treatment, that such minded-bodies are often fragmented (and reassembled) through (inter)corporeal transfers and that these processes involve emotional and corporeal relationalities which occur at many spatial registers. Secondly, I explore cancerous places, showing how creative sources can reveal their affective nature, the mobile nature of the cancer journey and the importance of active place-making by those living through, with and on from life-threatening illnesses. And, thirdly, the creative sources reveal the need to move beyond totalising narratives about cancer, in both questioning conceptual oppositions of life/death through revealing perspectives that traverse between livingdying, and in illustrating the multiplicities of livingdying in different places.

\section{Complex cancerous spaces}

\section{Acknowledging the differentially minded-body}

The autobiographical account is an approach that is inherently skeptical of homogenising narratives and universalising claims: experiences/feelings/outcomes with respect to cancer and its treatment vary greatly, such as with diagnosis type, socio-spatial location, place and through time. So as Figures 1 and 2 show, (differentially-felt) minded-body responses to cancer will vary over time; they will be different whilst having (distinctive types of) treatment, while in recovery, when 'in remission' or whilst living with a secondary diagnosis. They also alter with place: presentations of the livingdying self will vary if in the oncology ward, at home, at work, at a cancer support group. Then there are also spatial variations in health outcomes at a diversity of scales, which partly 
depend on the particular system of health provision and governance. In my case, the luxury of a 'free' National Health Service cannot be denied, although the delivery and embodied experience of this health service fluctuates greatly across the nation, region, hospital and ward ${ }^{\mathrm{xi}}$. The field of cancer care is cut through with social differences too (gender, race, class, etc); it is not only where in the world/region/nation/city we live, but it is also who we are that can influence health outcomes with respect to cancer and its 'survival', such as the food we can afford to buy, the knowledge we can accrue for self-care or how we are perceived by medical professionals. Finally, there are also biomedical differentiations, for example, depending on the type of cancer, the grade, treatment availability, the clinician's diagnostic skills and knowledge, how individual bodies react to particular treatment regimes, personal genetic make-up etc. So the autobiographical account points towards the need to avoid universalising presentations of minded-bodies with cancer that fail to adequately address specific biomedical, geographical, temporal, social and political contexts. It also illustrates the importance of embedding any discussion of living with and on within the multiply variegated specificity of a particular minded-bodied experience, one that recognises the manifold spaces from which cancer might be lived, experienced or written about.

\section{Fragmenting and reassembling minded-bodies through (inter)corporeal transfers}

In acknowledging this differentially minded-body, what other insights can the creative cathartic sources above provide? When considering living with and living on from cancer, minded-bodies are often fragmented, disassembled, incomplete, altered. Body parts may be permanently removed through surgery or parts of bodies may cease to function and then start to function again, or function in a different way. Minds can become disoriented in traversing between the memories of the body 'as-was', and bringing the newly reassembled body into psychological being and acceptance.

Bodies can also be remade through (inter)corporeal transfers from other parts of our own or others' bodies, through reconstructions, transplants or implants (Dickinson and Sothern 2013), sometimes from (unknown) people from other (unknown) parts of the world. This transgresses the idea of the 
unitary body, dispersing, blurring and perhaps even shattering (Philo 2014) the boundaries of the corporeal. So, for example, Figure 1 gives a flavor of my fragmenting and reassembling mindedbody (in a particular time and place) through surgery, chemical action, adjunctive treatment and radiotherapy. An image of my face underlies this long list of medicinal interventions, enabling me to engage in reverie regarding the associated changes to my fleshy contours and flows: 'Who am I now, do I recognize myself?', 'Where and how do I exist beyond these endless medical interventions, what pieces of me remain?' and, finally to assert, 'Yet despite all this, I am (still).'

Fragmented minded-bodies are not just remade through (inter)corporeal transfers based on biomedical practices, however, they are also reassembled through the flows of knowledge and the emotional transferences involved in affective and embodied care (Raghuram 2009). Such caring practices and knowledges used to provide oncology care circulate from multiple locations (Mukherjee 2011), as do the informal knowledge networks that provide emotional support, self-help and specialised patient knowledge through internet, telephone and face-to-face fora (Sharf 1997; Watts 2010). Forms of medicinal knowledge interact in an active but changing relationship with spiritual and emotional self-knowledge and expertise. Thus the fragmented minded-body is in a state of flux, continually (re)constructed through (inter)corporeal transfers involving circulations of biomedical and caring practices, flows of professional and informal knowledges and a plethora of embodied emotions.

\section{The multiple spatial registers of emotional and corporeal relationalities}

These circulations involve emotional and fleshy relationalities that play out through the mindedbody. They operate at multiple spatial registers, ranging from the global to the bodily interior (Colls and Fannin 2013), down to the scale of the cell and the molecular intra-cellular level. For example, organic molecules and cells (and in turn tissues and organs) can be actively influenced by reiterative links to emotional states (Siegel 1986): the state of mind can alter the state of the body through the central nervous, endocrine and immune systems (and vice versa) (see Figure 2). This is in addition 
to the active effect of the environment that frames our cells (Guthman and Mansfield 2013) and the biomedicinal interventions the body receives. The multitude of corporeal process occurring at the interior register are also in constant reiterative interaction with affective networks of others at other spatial registers: those giving us food to recycle vitality and decompose neoplasms, carcinomas, sarcomas; those mining metal to make instruments to cut our bodies, remove parts and discard them, enabling survival (sometimes); those everyday acts of kindness and care- folding sheets, giving flowers, making us laugh- which refresh the spirit and rekindle the life force. Although these emotional relations are intimately woven into the flesh, they often remain masked from health care accounts. Absent presences and concealed relations abound in the 'historically and spatially contingent body-worlds' (Cameron et al. 2013: 8) of cancerous spaces.

\section{Uncovering cancerous places}

\section{Affective cancerous places}

Cathartic methodologies can also provide insights into cancerous places. Figure 2 gives an account of an oncology ward, as written through a particular minded-body in a particular place at a particular point in time. It is an account that is emotionally rich- in terror, anger, appreciation, sickness and grief- illustrating the multitude of feelings flowing through my minded-body in the oncology ward. At the same time, Figure 2 also acknowledges the importance of 'suspending emotions' to enable psychological coping and survival, which is indicative of the limits to the affective response and relationship (see also Bissell 2010 and Madge 2014) and the aching solitude of the cancer journey. Moreover, Figure 2 gives some insights into the ultimate uncertainties that a cancer diagnosis can invoke, that I could no longer take my 'very existence for granted', a precarious state of living on the edge of life (see also Philo 2014) ${ }^{\mathrm{xii}}$. These unstable boundaries of life are illustrated in Figure 2 as a process of medical 'normalisation' took hold (in this case to the 'production line of chemotherapy'). This pushed my minded-body to the state of the living dead- a zombie-like, shadowy, liminal, disorientating existence of absent-presence- in which life space 
collapsed into the pin-head of repeated hospital visits and time became recalibrated through medicalised encounters and bodily reaction to them (rather than time being calibrated by work-time or school hours, for example). The account in Figure 2 is replete with the (only lightly hinted at, indeed almost unspeakable) multiple losses associated with the trauma of a cancer diagnosis: a whole body, a future security, an assured life. The angry writing is also indicative of the (mediated) agency of cancer 'patients', speaking out against hegemonic discourses of the heroic victim or the passive receptor of pharmacological/medicalised interventions; rather it is a meditation on the will to endure and endure some more. The creative accounts thus reveal that biomedical cancerous spaces have a richly affective register: they are minded-places.

\section{Moving through cancerous places}

Figure 3 pushes at this idea of the emotions involved in living on from illness, diagnosis and treatment of cancer. The juxtaposition of the three poems beside one another is a deliberate play on the space of words to loosen the linear scriptural format, evoking that we do not move 'beyond' our cancer in some simple predetermined manner, but rather we 'carry' the spiritual, fleshy, health burdens of the cancer with us as we potentially move towards a place of (emotional, physical, spiritual) recovery: there are no simple endings to a cancer diagnosis ${ }^{\text {xiii }}$. As is commonly stated, having cancer is a process, a journey that a minded-body moves through, not a fixed medical diagnosis and as such, cancer leaves psychological and corporeal traces (and absences) that have to be lived with. The three poems are situated next to one another for another reason too. The first poem was written the day after my last treatment in the oncology ward where I could sense a flavor of relocation, 'a repositioning towards a new beginning'. The second poem was written the day I returned to work in a move 'back to life, back to living' as my soul 'unfolded in sunlight', while the third poem is pungent with the allure of a future yet to happen 'a better place on the horizon, winking at me'. Arranging the poems beside one another illustrates that both extraordinary health care sites and mundane everyday work and home places can co-exist (think of those who carry on 
working while undergoing chemotherapy or the multitude of hormone therapies ingested at home). It is an attempt to counter a view that privileges my hospital experience as the linear start of mystory but instead aims to evoke a sensibility that a hospital ward, a walk home from work and a fiesta can all comingle and that we move through these various spaces (of physical and spiritual illness and well-being), sometimes simultaneously, as our medical treatment/healing progresses. The juxtaposition of the three poems also shows that hope and despair are not mutually exclusive, that past experience and future desires can run along beside each other: beside pain and uncertainty there may be some possibility of carving out some beauty, however fleeting and difficult that might be to grasp ${ }^{\mathrm{xiv}}$. This beauty is encapsulated in the photo onto which the poems are placed in Figure 3. It is a verdant, voluptuous, luxurious, fertile image- a celebration of the breathing, pulsating, emergent life force around us every day- which deliberately runs counter to the black and white 'frozen', harsh, lifeless image in Figure 2. The photo in Figure 3 is thus both a deliberate assertion of the beauty of life and a reminder that the therapeutic landscapes of cancer exist far beyond the oncology ward.

\section{Active minded place-making}

Moreover, as the third poem in Figure 3 illuminates, these therapeutic landscapes of healing, these 'better places' are as much minded, metaphorical, spiritual and emotional, as they are physical and material. Those living through, with and on from life-threatening illnesses have minded agency to create a vision of the world, and a way of being in the world- an active place-making- that not only helps them to survive, and survive some more, but also enables them to carve out a life worth living too. Recovery, staying well and healing are, after all, creative acts demanding perseverance and dedicated effort. In the trilogy of poems in Figure 3, I am therefore attempting to reclaim 'that space of agency where we know we are more than our pain' and this enables me 'to keep a sublime hold on life' (hooks 2009: 48, 52). But not 'giving ourselves over to sorrow' does not mean that we do not grieve, and do not carry on grieving, just that grief has 'its place' and the important thing is 'to 
keep a hold on life' (hooks 2009: 195). This is a process of learning to live in relation with loss, a place of no guaranteed consolations but rather the ongoing (sometimes) disquieting labour of living with and living on.

\section{Beyond totalising narratives: living with and living on}

\section{Traversing between livingdying}

Finally, the use of cathartic methodologies opens up questions surrounding the conceptual oppositions of life/death and offers perspectives that can uncover the simultaneity of dying, living with and living on (see also Maddrell 2013; Murray 2010; Watts 2010). Whilst being aware that in invoking non-dualism I am falling into a dualistic trap, I also acknowledge that refiguring dualisms is difficult, involving a wrestle with words, most likely to occur "near the boundary of what a writer can't figure out how to say readily, never mind prescribe to others' (Sedgwick 2003: 2). The accounts given in Figures 2 and 3 therefore hint at the possibility of traversing these dualistic tendencies and totalising narratives: they illustrate that there is no one fixed 'story' of cancer and its effects, but rather an ongoing process of despair, endurance and renewal, of crisis, recovery and transition, often expressed in intangible, uncertain and ambivalent ways in context of everyday lived life. For example, as Figure 2 reveals, during chemotherapy my cells were purposively obliterated precisely for the purpose of enabling life. (The form of chemotherapy I received, however, did not distinguish cancerous cells from other 'normal' fast growing cells in the blood, skin and stomach, so these cells were destroyed by chemotherapy too). Thus paradoxically, it was precisely this cellular death that provided the possibility of extended bodily life: there was no simple clear-cut opposition between my living and dying body in this example ${ }^{\mathrm{xv}}$. Indeed, all bodies are in a constant state of oscillation, of demise and renewal: cancer cells are developing in our body all the time but under 'normal conditions' they are destroyed by white blood cells before they develop into 'out-of-control' tumours. Cathartic methodologies can therefore provide a glimpse into this perpetual process of dissolution and regeneration, of livingdying. 


\section{The multiplicities of livingdying}

In addition, the view of death as the 'ultimate end of the life of a human body' may be a peculiar (Western, cosmopolitan, allopathic) way of thinking that is spatially, temporally and socially specific. Not all social groups/cultures/belief systems hold such a dichotomous view of living/dying (see authors, this issue). There is the need to 'provincialise' such views to acknowledge that there are (and have always been) multiple ways of thinking about livingdying, such as the chain of life, spectral presences in the living world, the deceased living in a place of light, living ancestors, reincarnation to other beings etc. So it is important to make space for multiple perspectives and viewpoints of livingdying as a continuum (which might include surprising, competing and contradictory perspectives being held in tension simultaneously). Cathartic methodologies may be one means to capture this continuum of a future with no guarantees, producing accounts that can traverse between these multiplicities of livingdying (as well as those of publicprivate, insideoutside, tranquilitytrauma see Rosenberg 2010: 246). In the following section three, I critically reflect on some methodological potentials and limitations raised through the use of creative cathartic methodologies.

\section{An emotive reflection on the (im)possibilities of creative cathartic methodologies}

Latest World Health Organisation statistics (Ferlay et al. 2013) demonstrate that breast cancer is by far the most common cancer in women worldwide, with 1.67 million new cases diagnosed in 2012. This accounts for nearly one quarter of all cancers diagnosed in women; it is also the most frequent cause of cancer death for women in 'developing' regions and the second most common in 'developed' regions. The rate of incidence in the UK is seventh highest worldwide (Ferlay et al. 2013). In 2011, 49,936 women and 349 men in the UK were diagnosed with invasive breast cancer in the UK and 11,684 women and 78 men in the UK died from this disease (http://www.cancerresearchuk.org/cancer-info/cancerstats/types/breast/), which is roughly 137 new 
diagnoses and 32 deaths per day. Given the significance of this disease, one that touches so many people's lives, with such devastating multifaceted impacts, what potentials can creative cathartic methodologies offer in undertaking research with those dying from, and living with and on from breast cancer (and other life-threatening illnesses)? Below I explore three key issues which I consider are important: changing research practices; enabling precarious theorising; and circumscribed creative agency.

\section{Research practice: approaching livingdying differently?}

First, I would propose that creative cathartic methodologies enable a way 'to write ourselves differently' (Tamas 2009: 1) in trauma studies, producing 'difficult and unknown affects, but ones that may provide new ways of talking about unspeakable events' (Parr and Stevenson 2014a: 1). As Figures 1 and 2 convey, the rather benign statistics above abstract the fleshy distress and visceral horror of being diagnosed and treated (with varying success) for such a life-threatening illness. Cathartic autobiographies can enable such topics to be approached 'otherwise'. For example, as Figure 1 demonstrates, a (breast) cancer diagnosis does not simply involve a one-off treatment 'package' but a grueling array of repetitive surgical, diagnostic and pharmacological interventions and practices which can last some time and having abiding effects. These biomedical procedures can result in a disjointed, disorientated and hyper-sensitive minded-body, one that is literally pushed to the limits of life (hence the skeletal, ghostly, just-about-present image underlying the text), leaving the continuing burden of living with ongoing side-effects even once treatment has finished. Moreover, Figure 2 demonstrates that the everyday physicality of medical 'events' can be (repeatedly) harrowing, disturbing and traumatic (as well as boring, life-affirming, emotionally rich etc), leaving traces and memories of embodied places (hospital beds, wards, hospices etc) that can evoke strong visceral and emotional responses long after treatment has finished (some people start sweating when they go near to the hospital in which they were treated, others are sick on entering 
oncology wards, others start crying when they see a syringe etc). Thus creative methodologies might be one way to attempt to research the painful, sensitive and turbulent issue of livingdying.

This is not, however, a straightforward research methodology to employ. For how can researchers convey/speak of/understand this specific trauma if they have not experienced it themselves? What are the limits to our understanding as people whose worlds have not been rocked or sense of self not turned inside out in this specific way ${ }^{\mathrm{xvi}}$ ? How might the researcher operationalise in praxis the hyper-sensitive reflexivity required for working with people with people with raw and fragmented minded-bodies, to ceaseless grapple with the production of academic work on livingdying? At minimum, researchers must be careful, thoughtful and compassionate in approach, recognising the complex vulnerabilities of those (and their family, friends, medical practitioners etc) who are going through the experience of dying, living through, with and on from a cancer diagnosis. However, just because this may be an incredibly difficult research process, I am not simply arguing that those with cancer can only speak for themselves (it would be naive to assume that the shared experience of cancer would result in a particular rapport or unified understanding). Rather, what I am suggesting is that such research be conducted with an engaged presence, the researcher becoming a privileged listener, 'being beside' the vulnerable in their pain. (See also Parr and Stevenson (2014b) who alert us to the possibilities of the practical actions that might be evoked through such listening and Tamas' (2014a) exploration of how objects and spaces might be used in the process of understanding trauma).

Here I draw on Eve Sedgwick's (2003) preposition of 'being beside', which offers 'some useful resistance to the ease with which beneath and beyond turn from spatial descriptors into implicit narratives of, respectively, origin and telos' (Sedgwick 2003: 8). In other words, 'being beside' is a way of thinking that helps traverse between past and future, which is less hierarchical (for several elements can run alongside one another), less oppositional (than the dualisms of either being a researcher or a participant or either having a mind or a body), that can transcend the troupe of the boundary, to potentially research more 'horizontally'. As Sedgwick (2003: 8) proposes 
however: 'Beside comprises a wide range of desiring, identifying, representing, repelling, paralleling, differentiating, rivalling, leaning, twisting, mimicking, withdrawing, attracting, aggressing, warping, and other relations.' In other words, this 'being beside' is a tricky process wrought with contradictory and potentially refuted relations. This is because, in most research situations, research relations are highly variegated and uneven with complex stratigraphies of power: so here I am highlighting the (emotional) hard labour that might be needed to work towards 'being beside' those in livingdying situations.

In employing the metaphor of 'being beside' those who are going through the experience of dying from, living with and living beyond a life-threatening illness, I am proposing a research practice which is not only hyper-sensitive in its attentiveness to the vulnerabilities of the research subjects but is also acutely aware of the limits to our understanding as researchers. In other words, there must be recognition of the limitations of 'speaking for' through an emotional health care geography: when bodies and minds are clouded with toxicity, medication, exhaustion, hurt and fear, even 'knowing' and expressing oneself to a researcher can become a challenge, or indeed an impossibility, as more important things- like enduring and surviving or spending time with loved ones- take precedence. Additionally, empathy can never be guaranteed: there is no automatic way of feeling or knowing another person's lifeworld (Madge 2014), especially in situations of livingdying. For example, how possible is it to convey (let alone apprehend) the faint fleshy memories of removed body parts? How can a researcher even begin to fathom the surreal and intangible nature of chemotherapy, and the sheer grit required to endure it? This (attempted) understanding must be laboured for by 'working through' an empathic opening, while being receptive to getting a surprising and unexpected response, or indeed no response at all (Bennett 2009; Madge 2014: 182; Noxolo et al. 2012: 418). This empathetic opening might be the briefest of moments, where a fissure opens up and a sense of mutuality, of 'being beside', might begin to develop, where feelings (or indeed, silences) might be exchanged, glimpsed or shared (see also Bondi 2014a on the methodological potentials of psychoanalysis to develop knowledge about another person's 
feelings). Such a moment of 'being beside' is captured in the words below, which I wrote on the oncology ward in response to my friend's encouragement to face another attempt at cannulation, which became increasingly difficult and painful as my treatment progressed:

Where does all the pain go

When you hold me tight

And whisper to me that I can do it

And I do?

\section{Towards precarious theorising?}

As the extract above intimates, 'being beside' those in pain from livingdying experiences is liable to require methodological shifts and different research practices. Sharon Rosenberg (2010: 249, 250) suggested that trauma can bring one to the limits of understanding, opening up gaps and disrupting familiar ways of speaking, writing and listening in the academy. She argued that when you lose what you come to count on as knowledge because of your trauma, when the guarantees of what you thought you knew (provisionally) slip away, this can result in a shift in the way that one thinks, researches and writes. According to Rosenberg (2010: 250) it can 'let something else happen, to allow in some other thought, to be open to what that facing does to the certainty of scholarship.' From this understanding she developed the idea of 'precarious theorising' and used creative nonfiction to learn the nuances of writing what cannot be fully known, learnt or communicated.

So drawing on Rosenberg's (2010) ideas, and emanating out of the cathartic process I used myself to account for my 'cancer journey', I would like to suggest that creative cathartic methodologies might be a means to build towards more uncertain 'precarious theorising', which is attentive to the limits of understanding, receptive to insights not yet understood. Creating while making, be it through art, poetry, writing, photography or creative bricolage, may be a means for the researcher to engage with the 'research subject' from their perspective, glimpsing the world through their eyes, 'being beside' them through the research process, potentially gaining some 
insight into the precarious, unpredictability of life itself. Creative exhalations may thus be a way to push at 'tidy, reasonable' academic discursive norms to recount 'messy, unreasonable stories... which produce both knowledge and empathy' (Tamas 2009: 1). Perhaps more than that too, for as Kearney (2007: 51) illustrates, narrative retelling and remembering can provide cathartic release for suffers of trauma. This is a process of 'redeeming losses by reframing them as sites of knowledge production' (Tamas 2009: 1). As such, employing creative methodologies might enable those going through livingdying situations to make some sort of imaginative cathartic move through the creative process, possibly stitching together some of the fragmented shards of the minded-body (c.f. Philo 2014: 286). As Tamas (2014a: 89) reveals ‘...healing derives, at least in part, from acknowledging traumatic experiences and bringing them into relationship through testimonial acts that reconstitute our ability to bear witness to ourselves and connect with others'. Enabling catharsis in the process of creative-making, as a 'side effect' of the research process, however, would require mature research expertise, probably psychotherapeutic or art therapy training and extremely careful handing, but it might ultimately enable living with and transforming the trauma of life-threatening illnesses, as I note below:

'When you share the pain, when you name the pain, it eases. You can move through the pain with words by externalising the pain you feel inside. This is an attempt to relocate the pain. By communicating pain it takes the hurt outside of your body. But this is a wrestle with words because of the inexpressibility of pain. In other words, it is not an easy thing to do. But for me, by externalising pain, by voicing it (through creative writing, or poetry, or art), by speaking pain, this allows catharsis. Catharsis is the experience of intense emotion that can assist you in working through a painful event, experience or feeling and so move you towards a calmer, more equitable state of being. Sadness, grief, fear and anger are crucial things to feel (in an appropriate place and time) to enable this ongoing process of 
rebalancing. Catharsis can facilitate the knitting together of the disorderly mind and hurting flesh, to help you keep on living, until you feel alive again.'

\section{Circumscribed creative agency?}

Creativity can also become a form of active agency, 'as the working of the imagination on the discursive and experiential resources available to the individual becomes a form of micro-political action and a potential subversion of dominant discursive formations' (Haynes 2006: 416). This suggests that creative agency might be a further potential of cathartic methodologies, a way of writing oneself (back) into being (c.f. Philo 2014: 285), of bearing 'witness to occurrences that cannot be understood or experienced in any other manner' (Tamas 2014a: 91). In Figure 1, for example, the charting of my medical journey was really important for me to be able to map the fleshy 'reality' of my experience of having cancer: too often representations of cancer in the media bore no reality whatsoever to my embodied experience of the illness. Moreover, Figure 2 enabled me 'to speak the truth' about the anger and despair I felt surrounding cancer, to counter the 'be strong' 'be brave' 'be positive' hegemonic narratives. Despite often feeling my minded-body was 'a $\operatorname{cog}$ in the oncology factory farm', expressing myself creatively allowed me to re-write my script surrounding cancer to produce a version that sat comfortably with my personal experience: it provided me with some agency.

While this creative impulse was important to embolden my sense of being (still) alive, as a stubborn recalcitrance and counterpoint to the death and tragedy I was experiencing daily, the ability to express myself and present a counter-narrative to hegemonic discourses was not, however, without limits. In other words, the agency of people facing life-threatening illnesses can be circumscribed, as bodies became weaker, as pain intensifies through repeated treatment, as spirits reach the limits of endurance, as control over body space become erased though repetitive medical practices. Moreover, catharsis is an ever changing process, and the multiple emotions involved may be fleeting, remain unexpressed, or indeed be inexpressible, indicating further limitations to the 
creative cathartic encounter. Furthermore, other problems with creative autobiographical storytelling exist: it can result in distortion as well as healing and release; the temporal discrepancy between the event and the narrative can result in a conflict of interpretations; it is impossible to unproblematically know and represent ourselves as the stories we tell are selective, containing silences and erasures, thus producing particular versions of the self; finally, what we create may be mutable, contradictory, open to misinterpretation and always historically and spatially contingent (Kearney 2007: 63-64; Longhurst 2012: 876-877; Smith 2012: 344).

So while a creative cathartic methodology might enable a researcher to approach their research practices differently, enabling both a cathartic release and potential agency in (varied) livingdying situations, this is an inherently difficult research strategy to employ, one that will need care-full reflexivity, long-standing research experience and professional support (e.g. through art therapist, cancer support worker etc) to ensure that the process does not 'open up' emotions and harm people who are already in an extremely vulnerable position (or, indeed, harm the researcher) ${ }^{\mathrm{xvii}}$. In other words, there are limitations to the use of creative cathartic methodologies, because the creative impulse may be constrained, or the researcher may not have the methodological expertise or emotional intelligence required, or the subject may be too painful, too intangible, too inexpressible- just too unbearable- for the 'research subject' to want (or be able) to articulate. In the final section four I raise some questions about the emotional and political questions that such limitations provoke.

\section{Coming to an end: Holding open openings (Rosenberg 2010) for space for politicised compassion in the academy?}

In researching the 'porosity of life-death' (Sidaway and Maddrell 2010: 9) from the 'inside', how can this experience be held open as a space of transformation, to live life differently? Here I want to 
revisit the anxieties and uncertainties articulated at the start of the paper to ask: What encounters are made possible through my account? Why subject myself to such an (indulgent? unwise? fragile?) form of embodied storytelling? What is the imperative and urgency to present such a risky account? In responding to these questions I am not concerned with a search for deterministic, definite answers or establishing fixed 'feeling rules' (Bondi 2005) but more interested in making gestures towards 'an opening into learning' (Rosenberg 2010) that provokes, unsettles and raises enquiries about what it means to be taught by the experience of (traumatised) others (see also Parr and Stevenson 2014b). In other words, through the encounter with my (specific) story about my own (im)mortality, does this mean anything for how we listen, learn and respond through 'our' living now? Does my embodied performance in this paper provoke any responses to everyday practices or compassionate outlooks, and if not, why not? What open possibilities (Butz 2010: 138) are (dis)enabled through my creative cathartic methodologies?

There may be a complex paradox at play in answering these questions. The dearth of emotional reflection about the troubling nature of conducting research with those living with and on may be precisely because of the difficulty of the subject, which must sear at the soul of most researchers, forcing them to face their own mortality. Rosenberg (2000: 77) speculates that researchers can produce an emotional veneer against this unbearability: 'a skin against the unbearable that is so profoundly difficult to know.' This emotional detachment is often a symptom of trauma studies but according to Rosenberg (2000: 85) we need to 'awaken to the fear, the vigilance, and the forgetting that is required (albeit to different degrees) in social regime of power in which everyday horrors pass as normal.' It is through this awakening, this difficult terrain which unsettles and disturbs, that critical and risk laden pedagogic potential might be opened out. This gestures towards the importance of an 'uncomfortable reflexivity' (Pillow 2003, quoted in Maddrell 2009: 682) that troubles over and acknowledges (in public writing rather than private reflection) the difficulties of undertaking such fragile and fraught research. It also gestures towards an approach that refuses to 'separate out' such troubling bodies and how they make us feel, from academic 
accounts and this is precisely because none of us can avoid the risk of death. In acknowledging that precarious relationship with death, compromises will have to be made with 'ontological security' (Woodthorpe 2010: 60, quoting Giddens 1984; see also Bondi 2014b).

If such a step is taken towards the risky acknowledgement of the emotional demands of research into livingdying, this will present challenges to some contemporary debates that seek to present death, dying and living on as 'sanitised neutral experiences'. It might move debates towards more 'layered' understandings that highlight the connections between the visceral, emotional and political spheres (both within and beyond 'the hospital walls'), that shape experiences and outcomes with respect to living through, with and on. In other words, an approach that cannot avoid consideration of the context of current health care policy and governance (in particular places), so the (differentiated) experiences of those living with and living on are examined with explicit consideration of the environment that frames them. Bodies, after all, are not separable from political processes (at a variety of scales) but intimately entangled with them (Sidaway 2009). Hence, concern here is not limited to caring for those who are living with or living on but also extends to caring about the complex conditions that shape these experiences (c.f. Tronto 1993), including the ever changing capacity of the nation state to intervene in the body-state (Cameron et al. 2013: 2).

In the UK, for example, the Coalition government is currently going through a process of welfare reform (Welfare Reform Act 2012) which is predicted to have many varied and negative impacts on those living with and on from cancer. Ramesh (2013) for example, indicates that this may result in 20,000 cancer patients loosing up to six million pounds as benefits rise more slowly than living costs, while Leeming (2013) documents that bedroom tax, reduced eligibility to receive tax credits and the reduction in advice services due to spending cuts are all likely to have further damaging effects. Facing mortality (or that of a loved one) brings with it the ultimate uncertaintythat of an assured future- which fosters multiple insecurities. Those living in such precarious and vulnerable situations do not need difficulty in procuring their basic needs (a warm home, essential medical equipment, clothing or medication, the costs of transport to hospital, rent or bills, or the 
stress of having to go back to work before having had enough time to recover). These considerations of the political policies associated with cancer are likely to become more imperative, as it is predicted by 2020 almost half of the UK population is likely to have had a cancer diagnosis in their lifetime (MacMillan Cancer Support 2014).

Such political processes are not fixed: they can be negotiated, resisted and transformed in a multitude of ways too ${ }^{\text {xviii }}$. This raises implications for all of us as academics, for it intimates that we cannot avoid consideration of current academic working practices, cultures and relations and how these abstract processes are literally experienced and felt 'in the realities of the flesh' (Cameron et al. 2013: 3). The academy is constantly 'in the making' (Hawkins et al. 2014; Madge et al. 2014; Tamas 2014b), becoming reshaped and remade on a daily basis owing to the everyday ideas, practices and norms of academics (and students, administrative staff, educational policy makers, politicians etc). The academic landscape is also enacted through a multiplicity of relationships between the many people involved in its making. The question then arises, how might using embodied, passionate, cathartic minded-body accounts move us towards 'doing' the academy differently? As colleagues, friends, resource managers, awarders of grants and peer-reviewers of papers, how might we conduct our everyday relations and practices with those experiencing living through, with and on, with determined compassion? Although the requirement for employers to support the differentiated constituency of those living with and through cancer (and other lifethreatening illnesses) in their work environment is well established (NCRI 2010), how embedded are such policies in the everyday academic lives of Geography Departments ${ }^{\mathrm{xix}}$ ? And what more is needed than regulatory policy interventions and technical/architectural adjustments, that might involve questioning abilist norms and exclusions, micro-scale cultural practices and socialites and the 'perverse illogic' of the academy in terms of attainment, competitiveness and productivity (Chouinard 2011; Horton and Tucker 2014)?

So here I am urging acceptance of abject, difficult (mourning, painful, dying, grieving, incomplete) bodies within academic spaces, to see beyond the cancer victim/hero, to admit the 
dying into the world of the living. I am not, however, proposing an individualistic responsibility; rather, I follow others (Lawson 2007; Noxolo et al. 2008; Waite et al. 2014) in adopting a relational morality that recognises 'the affective affiliation between those in diverse situations' and which explores how differences might be bridged through emotional proximity predicted on notions and enactment of compassion (Waite et al. 2014, 327). This is unlikely to be an easy process, because it is demanding to perform ordinary everyday acts of kindness in the marketised and privatised spaces of higher education: acting compassionately may involve costs in terms of (material, embodied, reputational) self-interest and difficult emotional feelings. However, working through these difficult edges of a compassionate politics is a worthwhile endeavour, to carve out a way of living and being in the academy which involves conducting everyday intimate encounters and relations with each other with an enduring sensibility of empathy and kindness, while also challenging the structural conditions within and beyond the university walls that result in the habitual exclusionary practices of geography workplace institutional life. This traversing between an everyday compassion for others and enacting a broader agenda of justice, while retaining one's own physical and emotional sanity within the spaces, subjectivities and expectations of the neoliberalising university, is likely to be a challenging terrain with unpredictable effects and non-auditable outcomes. It will require a provocative (re)imagination of what is valued within everyday academic working culture, a recognition of the limitations of 'speaking for' through an compassionate political agenda (Noxolo et al. 2012) and constant vigilance to ensure compassion does not become 'privatised' to focus only on personal actions while broader structural inequalities remain hidden, resulting in the (inadvertent) depoliticisation of justice agendas (Mostafanezhad 2013).

This politics of compassion might normalise 'doing things differently' (Hansen and Philo 2007), openly encourage and support a multitude of different bodies in the academy and recognise that such bodies have always been an important component of the academy, making it what it is. It is also a political project that might question the relentless (self)disciplining of such bodies to the taxing demands of the neoliberalising academy, and make space for all marginal and marginalised 
bodies (not just those living through, with or on from cancer) (see Horton and Tucker 2014). This gestures towards a way of living and being in the academy that might be more inclusive, more compassionate, and ultimately more emotionally and corporeally healthy, for all of us.

\section{Acknowledgements}

I appreciate the generous and insightful comments made by the reviewers. I would also like to thank Avril Maddrell, Olivia Stevenson, Katy Bennett, Parvati Raghuram and Jen Dickinson whose perceptive insights helped strengthen the paper. Finally, thanks to all my family $(\mathrm{R}+\mathrm{Sx})$, friends and colleagues who have steadfastly been 'beside me' during my cancer journey. Thanks also to Laura Vann and Kerry Allen for converting the figures to the correct file format.

\section{References}

Báez-Hernández S (2012) The acquired, Social Semiotics 22: 103-106.

Bennett K (2009) Challenging emotion, Area 41: 244-51.

Bissell D (2010) Placing affective relations: uncertain geographies of pain, in Anderson B and Harrison P (eds.) Taking-Place: Non-representational Theories and Geography. Ashgate, Surrey, pp. 79-98.

Bondi L (2005) The place of emotions in research: from partitioning emotion and reason to the emotional dynamics of research relationships, in Davidson J Bondi L and Smith M (eds.) Emotional Geographies. Ashgate, Surrey, pp. 231-246.

Bondi L (2014a) Understanding feelings: Engaging with unconscious communication and embodied knowledge, Emotion, Space and Society 10: 44-54.

Bondi L (2014b) Feeling insecure: a personal account in a psychoanalytic voice, Social and Cultural Geography 15: 332-350.

Butz D and Besio K (2009) Autoethnography, Geography Compass 3: 1660-1674. 
Butz D (2010) Autoethnography as sensibility, in DeLyser D Herbert S Aitken S Crang M and McDowell L (eds.) The Sage Handbook of Qualitative Research. Sage, London, pp. 138155.

Cameron A Dickinson J and Smith N (2013) (eds.) Body/State. Surrey: Ashgate.

Chouinard V (2011) 'Like Alice through the looking glass' II: the struggle for accommodation continues, Resources for Feminist Research 33: 161-178.

Chouinard V (2012) Mapping bipolar worlds: Lived geographies of 'madness' in autobiographical accounts, Health \& Place 18: 144-151.

Colls R and Fannin M (2013) Placental surfaces and the geographies of bodily interiors, Environment and Planning A 45: 1087- 1104.

Davidson J and Henderson VL (2010a) 'Coming out' on the spectrum: autism, identity and disclosure, Social and Cultural Geography 11: 155-170.

Davidson J and Henderson VL (2010b) ‘Travel in parallel with us for a while': sensory geographies of autism, The Canadian Geographer/Le Géographe Canadien 54: 462-475.

Daya S (2011) Performing place, mobility and identity in South Africa, Area 43: 488-494.

de Leeuw S Parkes MW and Thien D (2014) Questioning medicine's discipline: The arts of emotions in undergraduate medical education, Emotion, Space and Society 11: 43-51.

DeShazer MK (2012) Postmillennial breast cancer photo-narratives: Technologized terrain, Social Semiotics 22: 13-30.

Dickinson J and Sothern M (2013) Organ transplantation: the debt of life?, in Cameron A Dickinson J and Smith N (eds.) Body/State. Ashgate, Surrey, pp. 51-64. 
Donovan C and Moss P (2014) Methodologies of intimate writing I, II and III. Special Sessions Organized for the Annual Association of American Geographers, Tampa, Florida, April 812.

Duffy M (2013) The requirement of having a body, Geographical Research 51: 130-136.

Evans R (2014) Parental death as a vital conjuncture? Intergenerational care and responsibility following bereavement in Senegal, Social and Cultural Geography DOI:10.1080/14649365.2014.908234.

Ferlay J Soerjomataram I Ervik M Dikshit R Eser S Mathers C Rebelo M Parkin DM Forman D Bray F (2013) Globcan 2012 v1.0 Cancer Incidence and Mortality Worldwide: IARC Cancer Base No. 11. International Agency for Research on Cancer. Lyon, France. http://globocan.iarc.fr (Accessed May 2014).

Frank A (2000) Illness and autobiographical work: dialogue as narrative destabilization, Qualitative Sociology 23: 135-156.

Ginn F (2013) Death, absence and afterlife in the garden, Cultural Geographies DOI: $10.1177 / 1474474013483220$.

Glover TD and Parry DC (2009) A third place in the everyday lives of people living with cancer: Functions of Gilda's club of greater Toronto, Health \& Place 15: 97-106.

Gould P (2010) Art and mourning in an Antarctic landscape, in Maddrell A and Sidaway JD (eds.) Deathscapes: Spaces for Death, Dying, Mourning and Remembrance. Ashgate, Surrey, pp. 281-297.

Guthman J and Mansfield B (2013) The implications of environmental epigenetics: A new direction for geographic inquiry on health, space, and nature-society relations, Progress in Human Geography 37: 486-504. 
Hansen N and Philo C (2007) The normality of doing things differently: bodies, spaces and disability geography, Tijdschrift voor Economische en Sociale Geografie 98: 493-506.

Harrington CB Hansen JA Moskowitz M Todd BL Feuerstein M (2010) It's not over when it's over: long term symptoms in cancer survivors: a systematic review, International Journal of Psychiatry Medicine 40: 163-181.

Hawkins H (2011) Dialogues and doings: Sketching the relationships between Geography and Art, Geography Compass 5/7: 464-478.

Hawkins H (2012) Geography and art. An expanding field: Site, the body and practice, Progress in Human Geography 37: 52-71.

Hawkins R Manzi M and Ojeda D (2014) Lives in the making: power, academia and the everyday, ACME: An International E-Journal for Critical Geographies 13, 2 http://www.acmejournal.org/vol13/HawkinsManziOjeda2014.pdf (Accessed May 2014).

Hayes-Conroy A (2010) Feeling slow food: Visceral fieldwork and empathetic research relations in the alternative food movement, Geoforum 41: 734-742.

Haynes K (2006) Linking narrative and identity construction: using autobiography in accounting research, Critical Perspectives on Accounting 17: 399-418.

Hones S (2008) Text as it happens: literary geography, Geography Compass 2: 1301-1317.

hooks b (1995) Art on my Mind. Visual Politics. New York: New Press.

hooks b (2009) Belonging. A Culture of Place. Abington: Routledge.

Horton J and Tucker F (2014) Disabilities in academic workplaces: experiences of human and physical geographers, Transactions of the Institute of British Geographers 39: 76-89.

Hulme M (2013) Geography and the humanities, Progress in Human Geography 37: 306-317. Jay D (2012) The SCAR project, Social Semiotics 22: 39-46. 
Jenkings KN Megoran N Woodward R and Bos D (2012) Wootton Bassett and the political spaces of remembrance and mourning, Area 44: 356-363.

Katz C (2013) Playing with fieldwork, Social and Cultural Geography 14: 762-772.

Kearney R (2007) Narrating pain: The power of catharsis, Paragraph 30: 51-66.

Kettenmann A (2002) Frida Kahlo 1907-1954: Pain and Passion. Koln: Taschen.

Kleinman A (1988) The Illness Narratives. New York: Basic Books.

Krupar SR (2012) The biopsic adventures of mammary glam: breast cancer detection and the practice of cancer glamour, Social Semiotics 22: 47-82.

Lawson V (2007) Geographies of care and responsibility, Annals of the Association of American Geographers 97: 1-11.

Leeming C (2013) How cancer patients have been hit by welfare reform, The Guardian June 4th http://www.guardian.co.uk/society/2013/jun/04/cancer-patients-welfare-reforms (Accessed June 2013).

Liaschenko J Peden-McAlpine C Andrews GJ (2011) Institutional geographies in dying: Nurses' actions and observations on dying spaces inside and outside intensive care units, Health \& Place 17: 814-821.

Longhurst R (2012) Becoming smaller: Autobiographical spaces of weight loss, Antipode, 44: 871888.

Macmillan Cancer Support (2014) Cancer in the UK 2014. The State of the Nation Report. http://www.macmillan.org.uk/Documents/AboutUs/WhatWeDo/CancerintheUK2014.pdf (Accessed May 2014).

Maddrell A (2009) A place for grief and belief: the Witness Cairn, Isle of Whithorn, Galloway, Scotland, Social and Cultural Geography 10: 675-693.

Maddrell A (2013) Living with the deceased: absence, presence and absence-presence, Cultural Geographies 20: 501-522. 
Maddrell A and Sidaway JD (2010) (eds.) Deathscapes: Spaces for Death, Dying, Mourning and Remembrance. Surrey: Ashgate.

Madge C (2014) On the creative (re)turn to geography: poetry, politics and passion, Area 46: 178185.

Madge C Raghuram P and Noxolo P (2014) Conceptualising international education: from international student to international study, Progress in Human Geography DOI: $10.1177 / 0309132514526442$.

Mignolo WD (2011) The global south and world dis/order, Journal of Anthropological Research 67: $165-187$

Milligan C Kearns R Kyle RG (2011) Unpacking stored and storied knowledge: Elicited biographies of activism in mental health, Health and Place 17: 7-16.

Moore A Carter B Hunt A Sheikh K (2013) 'I am closer to this place': Space, place and notions of home in lived experiences of hospice day care, Health and Place 19: 151-158.

Morris SM and Thomas C (2005) Placing the dying body: emotional, situational and embodied factors in the preferences of place for place of final care and death in cancer, in Davidson $\mathrm{J}$ Bondi L and Smith M (eds.) Emotional Geographies. Ashgate, Aldershot, pp. 19-31. Moss P (1999) Autobiographical notes on chronic illness, in Parr H and Butler R (eds.) Mind and Body Spaces. Routledge, London, pp. 155-166.

Moss P (ed) (2001) Placing Autobiography in Geography. New York: Syracuse University Press. Moss P (2014) Enacting my fatigued body. Paper presentation at the Annual Association of American Geographers, Tampa, Florida, April 8-12.

Mostafanezhad M (2013) The geography of compassion in volunteer tourism, Tourism Geographies $15: 318-337$

Mukherjee S (2011) The Emperor of all Maladies: A Biography of Cancer. London: Harper Collins. 
Murray M (2010) Laying Lazarus to rest: the place and space of the dead in explanations of near death experiences, in Maddrell A and Sidaway JD (eds.) Deathscapes: Spaces for Death, Dying, Mourning and Remembrance. Ashgate, Surrey, pp. 37-56.

National Cancer Research Institute (NCRI) (2010) Rapid Review of Research in Survivorship after Cancer and End of Life Care http://www.ncri.org.uk/includes/Publications/reports/rapid_review_seolc2010.pdf (Accessed May 2013).

National Cancer Survivorship Initiative (NCSI) (2013) Living with and Beyond Cancer: Taking Action to Improve Lives. London: Department of Health.

Noxolo P Raghuram P and Madge C (2008) Geography is pregnant' and geography's milk is flowing': metaphors for a postcolonial discipline?, Environment and Planning D 26: 146168.

Noxolo P Raghuram P and Madge C (2012) Unsettling responsibility: postcolonial interventions, Transactions of the Institute of British Geographers 373: 418-429.

O’Neill M (2009) Ephemeral art: the art of being lost, in Smith M Davidson J Cameron L Bondi L (eds.) Emotion, Place and Culture. Ashgate, Surrey, pp. 149-162.

Parr H (2006) Mental health, the arts and belongings, Transactions of the Institute of British Geographers 31: 150-166.

Parr H and Stevenson O (2014a) 'Sophie's story: writing missing journeys', Cultural Geographies DOI: $10.1177 / 1474474013510111$.

Parr H and Stevenson O (2014b) 'No news today': talk of witnessing with families of missing people, Cultural Geographies DOI: 0.1177/1474474014530962.

Philo C (2014) Insecure bodies/selves: introduction to theme section, Social and Cultural Geography 15: 284-290. 
Purcell M (2009) Autobiography, in Kitchin R and Thrift N (eds.) International Encyclopedia of Human Geography. Elsevier, Oxford, pp 234-239.

Raghuram P (2009) Caring about the brain drain in a postcolonial world, Geoforum 40: 25-33.

Ramesh R (2013) Cancer patients face cash cuts under benefits bill, say charities, The Guardian $17^{\text {th }}$ February http://www.guardian.co.uk/society/2013/feb/17/cancer-patients-cuts-benefitsbill-charities (Accessed June 2013).

Rosenberg S (2000) Standing in circle of stone: rupturing the binds of emblematic memory, in Simon RI Rosenberg S and Eppert C (eds.) Between Hope and Despair: Pedagogy and the Remembrance of Historical Trauma. Rowman Littlefield, New York, pp. 75-90.

Rosenberg S (2010) Facing losses/losing guarantees: a meditation on openings to traumatic ignorance as a constitutive demand, in Kilby J Roland A and Crenshaw R (eds.) The Future of Memory. Berghahn Books, Oxford, pp. 245-263.

Sedgwick E (2003) Touching Feeling: Affect, Pedagogy, Performativity. Durham and London: Duke University Press.

Shafi N (2010) Poetry therapy and schizophrenia: Clinical and neurological perspectives, Journal of Poetry Therapy: The Interdisciplinary Journal of Practice, Theory, Research and Education 23: 87-99.

Sharf BF (1997) Communicating breast cancer on-line: support and empowerment on the internet, Women and Health 26: 65-84.

Shaw W (2013) Auto-ethnography and autobiography in geographical research, Geoforum 46: 1-4. Sherry Jr JF and Schouten JW (2002) A role for poetry in consumer research, Journal of Consumer Research 29: 218-234.

Sidaway JD (2009) Shadows on the path: negotiating geopolitics on an urban section of Britain's South West Coast Path, Environment and Planning D: Society and Space 27:1091-1116. 
Siegel B (1986) Love, Medicine and Miracles. St Ives: Random House.

Smith N (2012) Embodying brainstorms: the experiential geographies of living with epilepsy, Social and Cultural Geography 13: 339-359.

Sontag S (1983) Illness as Metaphor. London: Penguin.

Tamas S (2009) Writing and righting trauma: Troubling the autoethnographic Voice, Forum Qualitative Sozialforschung / Forum: Qualitative Social Research 10(1) Art. 22, http://nbnresolving.de/urn:nbn:de:0114-fqs0901220 (Accessed May 2013).

Tamas S (2104a) Scared kitless: Scrapbooking spaces of trauma, Emotion, Space and Society 10: 87-94.

Tamas S (2014b) Subject to loss, Emotion, Space and Society 11: 61-63.

Tighe M Molassiotis A Morris J Richardson J (2011) Coping, meaning and symptom experience: a narrative approach to the overwhelming impacts of breast cancer in the first year following diagnosis, European Journal of Oncology Nursing 15: 226-232.

Tronto JC (1993) Moral Boundaries: A Political Argument for an Ethic of Care. New York: Routledge.

Tucker J (2010) The lido in the forest: memory, landscape, painting, in Anderson E Maddrell A McLoughlin K Vincent A (eds.) Memory, Mourning, Landscape. Editions Rodopi, Amsterdam, NLD, pp. 191-203.

Tyner JA (2014) Dead labor, landscapes, and mass graves: Administrative violence during the Cambodian genocide, Geoforum 52: 70-77.

Vanolo A (2104) Locating the couch: an autobiographical analysis of the multiple spatialities of psychoanalytic therapy, Social and Cultural Geography 15: 368-384.

Waite L Valentine G and Lewis H (2014) Multiply vulnerable populations: mobilising a politics of compassion from the 'capacity to hurt', Social and Cultural Geography 15: 313-331. 
Watts JH (2010) 'It's not really like a hospice': Spaces of self-help and community care for cancer, in Maddrell A and Sidaway JD (eds.) Deathscapes: Spaces for Death, Dying, Mourning and Remembrance. Ashgate, Surrey: pp. 19-36.

Woodthorpe K (2010) Buried bodies in an East London cemetery: re-visiting taboo, in Maddrell A and Sidaway JD (eds.) Deathscapes: Spaces for Death, Dying, Mourning and

Remembrance. Ashgate, Surrey, pp. 57-77.

Worth N (2008) The significance of the personal within disability geography, Area 40: 306-314.

Young C and Light D (2013) Corpses, dead body politics and agency in human geography: following the corpse of Dr Petru Groza, Transactions of the Institute of British Geographers 38: $135-148$.

\section{Captions}

Figure 1 One minded-body (Source: Madge)

Figure 2 The chemo suite (Source: Madge)

Figure 3 A painful but hopeful trilogy (Source: Madge)

\section{Notes}

${ }^{\mathrm{i}}$ Although from the outset it must be acknowledged that this disembodied distancing may precisely be a way of responding to fleshy pain. Also, paradoxically, to a certain extent I too have employed this disembodied distancing as a (sub-conscious) ambivalent writing strategy (the text traverses between my embodied presence being known/unknown, being present/absent). In other words, writing autobiographically about the subject of breast cancer feels very risky, very self-exposing. In order to 'care for my soul', I have (to a degree) compartmentalised the emotive autobiographical Figures and the more disembodied academic account.

ii Throughout the paper I use illness to refer to the emotional and corporeal response to the disease of cancer.

iii Indeed, there are an estimated 2 million 'cancer survivors' in the UK (predicted to grow to over 3 million by 2030) (NCSI 2013: 5), while many women (and some men) in the UK are also currently 
living with a secondary (metastatic) breast cancer diagnosis: NCSI (2013:21) estimates that 24,000 people live with the progressive illness of breast cancer and 12,000 are in end-of-life care. It must also be acknowledged that 32 percent of people in the UK with a cancer diagnosis die within one year of diagnosis, many are diagnosed too late, are shown a lack of compassion or denied a 'good' death (MacMillan Cancer Support 2014), so living on and from cancer should not be over-valorised. Cancer is a horrible, destructive and painful disease.

iv These long-term impacts of a cancer diagnosis are recognised by the medical profession in the UK with an automatic life-long registration of a disability once diagnosed with cancer.

${ }^{v}$ Autobiography has also been employed elsewhere in Geography (Longhurst 2012; Moss 2001; Tamas 2014b) and see Butz (2010) for a review and a discussion of the auto-ethnographic sensibility.

${ }^{\text {vi }}$ I choose to call these poems; others might not (see Madge 2014).

vii The use of livingdying is a deliberate textual strategy to try and capture the reiterative and continuously morphing character of the relationship between the living and dying (see also Maddrell 2013 on the absence-presence relationship of the living with the deceased).

viii This particular emotional response is not assumed, of course. Some might be uninterested or unmoved, for it cannot be predicted how the paper might be read nor how its meaning might unfold because the text is 'a contextualized and always emerging geographical event' (Hones 2008: 1301).

ix This paper was written at a particular moment in my cancer journey, as I emerged back into the academy and life after cancer treatment. Everything seemed so vibrant, with different ideas sparking in all directions. The paper is consequently a rather undisciplined piece of writing in terms of its form/style, traversing between methodology, substantive geographical content and political intentions. These different directions of the paper reflect the untrammeled feelings of creativity I was having as I was writing myself 'back into (academic) being' (c.f. Philo 2014). Moreover, one of the underlying rationales of the paper is to investigate autobiography as a method in order to explore how it might expose different understanding of geographies of death and dying and to examine what 'openings into learning' this might generate. In other words, the linkage between methodology, geography and politics is a key feature of this paper, so it is inevitably broad in focus.

${ }^{x}$ The image of a roaring woman was inspired by Jo Shapcott's poem 'Hairless' in 'Of Mutability' (2010).

${ }^{x i}$ Although free on delivery, the National Health Service in the UK is funded through taxation.

xii This insecurity is the position of billions of people the world over, now and in the past, for life certainty/security is the luxury of the socially, geographically, healthily privileged.

xiii It must also be acknowledged, however, that these three poems do have a symbolic representation of a linear trilogy of a past, a present and a future, a tripartite world vision, hinting at the difficulty of developing writing strategies that are unencumbered by a legacy of linear sensibility, that can 'disobey epistemic rules' and that can move towards a position of unlearning 'global linear thinking' (Mignolo 2011) to relearn other ways of being. Moreover, while the static nature of the photographic images might be seen to raise a further problematic by 'freezing' my cancer journey at a specific moment in time, here I am using the images as a rhetorical devise, to 
tell a story, to act as a site of transformation rather than simply depicting an event (Tamas 2014a: 91).

${ }^{\text {xiv }}$ Hope is rarely guaranteed but has to be actively worked towards. Moreover, it is a particular emotional response, or way of being in the world, that may well be socially and spatially specific: hopefulness necessitates an understanding or belief in a secure future orientation which may well not be the case for many cancer 'survivors' (and others) in many parts of the world/nation.

${ }^{\mathrm{xv}}$ Although in other situations there may be (distressing, painful, traumatic) corporeal finality associated with cellular death.

${ }^{x v i}$ Thanks to Katy Bennett for this particular phrasing.

xvii I take on board Bondi's (2014b) point that qualitative research practice often already uses psychoanalytical techniques, such as the receptive unconscious in the establishment of rapport. I would, however, also endorse her view that use of such techniques might require professional support (see also Bennett 2009).

xviii This is evidenced by the successful campaigning in the UK to protect cancer patients from welfare changes with respect to Employment and Support Allowance and by recent calls by Macmillan Cancer Support (http://www.macmillan.org.uk/Aboutus/News/Latest_News/UKcancercarecrisislooming,warnsnewr eport.aspx) for all political parties to prioritise cancer in their manifestos with respect to delivering cancer outcomes that match the best in Europe, ensuring cancer patients are treated with the highest levels of respect and dignity and improving end of life care.

${ }^{x i x}$ Here I am thinking of practices such as continued long-term sick pay, graduated returns to work, reasonable adjustments to teaching obligations, attention to timetabling, reduction in REF outputs without long-term career damage etc, all of which have resource implications and make demands on everyone involved. 